Session 2692

\title{
Advancing Women in STEM disciplines to Leadership Roles in Academe
}

\author{
Deborah J. O'Bannon, Department of Civil and Mechanical Engineering, \\ Linda S. Garavalia, Department of Psychology, \\ David O. Renz, Bloch School of Business and Public Administration, and \\ S. Marie McCarther, Midwest Center for Non-Profit Leadership \\ University of Missouri-Kansas City
}

\begin{abstract}
This paper describes an NSF ADVANCE-funded program designed to facilitate the rise of faculty women to academic leadership positions in NSF-sponsored disciplines. Included are a detailed description of the major components of the Leadership Institute, characteristics of the women faculty members who enrolled in the 4-day program, a summary of participants' leadership activities to date, and an analysis of participants' pre-institute leadership goals. Sixteen women faculty participated in this first of three leadership institutes. Data from these participants regarding the value and effectiveness of the first institute are presented as well as conclusions and plans for future work.
\end{abstract}

\section{INTRODUCTION}

The purposes of this paper are twofold. First, we describe the rationale behind and the development and implementation of a National Science Foundation (NSF)-sponsored Leadership Institute for tenured faculty women in Science, Technology, Engineering and Mathematics (STEM). Secondly, we describe the participants, their leadership activities prior to attending the Institute, their perceptions of the value of the Institute, and any changes in their leadership activities at the end of the academic year in which the Institute was attended.

The goal of the Leadership Institute is to increase the representation of women in higher education leadership positions (chair, dean, etc.), and support the NSF ADVANCE goal "to facilitate women's advancement to the highest ranks of academic leadership." The Institute is limited to women who have already received tenure and are in areas of study supported by NSF (biology/biochemistry, chemistry, computer science, economics, engineering, geology, mathematics, physics, political science, and technology). The Leadership Institute is designed to increase the accessibility of such training for faculty in the Midwest by providing workshops within their geographic area at low cost. The leadership training focuses on the business and leadership skills needed for women to make a successful entry into department chair and dean positions.

\section{A. Women in Academic Leadership Positions in STEM disciplines}

The published literature is sparse regarding women in leadership positions in the STEM disciplines. The lack of literature is most likely due to the small number of women faculty in STEM and an even smaller number who have risen to leadership positions. Two significant publications by the National Academy of Sciences (Long, 2001 and National Academy of Sciences, 2000) report low numbers, less than 20 percent, of women who earned tenure in 
science and engineering. Both publications end their analyses of women's success with tenure, but, as these tenured women are the available pool for leadership positions, the reports illustrate the bleak potential for substantially increasing the number of women from science and engineering as academic leaders.

Nelson (2002) reports the percentage of department chairs held by women and minority men for several disciplines in the sciences and engineering; percentages ranged from 4 (computer science) to 29 (electrical engineering) with a median of $13.5 \%$. Nelson's data do not distinguish between female and Asian or minority male chairs; however, one would not expect that women would completely populate the chair positions. Departmental chairs provide the most significant pool for dean candidates and a small chairwoman pool will presumably yield a smaller number of sitting female deans. In fact, only 15 women are deans of engineering programs (as an example) (Layne, 2003), out of a total engineering dean population in excess of 300.

Nonetheless, some women in academic leadership positions remain hopeful. Greenwood (2000), who is president of one of the University of California campuses, believes "There is promise that in the next 30 years there will be substantially more female leaders in many areas of science." A recent article in the Chronicle of Higher Education (Lively, 2000) quotes a major search firm as saying, "We are five or six years away from the floodgates opening up" regarding successful women candidates for university presidencies. In addition, some research suggests that obstacles, such as failure to be awarded department chair slots, may not necessarily impede women's progress. McKenney and Cejda (2001) report that, while some women are promoted predictably from faculty to department chair to dean's office, some women are able to jump over intermediary layers. They conclude, "it would appear that for women a variety of credentials and experiences have become the medium of exchange."

\section{Leadership Institute Development and Implementation}

There are many anecdotal examples of well-meaning administrators promoting under-prepared women, followed by sad stories of how these otherwise talented individuals failed because of poor financial and/or leadership skills. "Often faculty members are unaware of the roles and responsibilities of an administrator and are unsure whether to accept such a position...' you go from being served to serving." (Greene \& Van Kuren, 1995). Excellent leadership workshops exist to prepare faculty and educational administrators for administrative positions. The wellknown Summer Institute for Women in Higher Education Administration at Bryn Mawr is one such program. However, it requires a substantial time commitment, and, in these tight budget times, a high financial commitment as well. Within Missouri, the University System sponsors a President's Academic Leadership Institute, but it is only open to sitting department chairs. It is not open to faculty preparing for chairmanships or positions in deans' offices.

A need exists for affordable and accessible leadership training for faculty women in the sciences who are in the stage of considering making the leap from faculty member to administrator. The leadership institute described in this paper is designed to allow women faculty to explore opportunities in leadership, and be prepared when opportunities for advancement arise so that the on-the-job learning is minimized and success is more likely. The opportunity to obtain business and leadership training before entering an academic leadership position gives these women faculty a strategic advantage. 
The institute described in this paper was funded by an NSF ADVANCE award, spanning three years and supporting three cohorts of Institute participants. This paper describes the first year of the Institute. Each cohort is small in number, 15-30 women, because the sessions are designed to be interactive with individualized materials. Each year, the Institute was delivered as two separate sessions, each two days in duration (four days total). The content of the Institute was developed and delivered by faculty and staff from the Midwest Center for Nonprofit Leadership (MCNL) at the University of Missouri-Kansas City. The sessions were similar to other nonprofit leadership development programs, with special attention to women in academia. They are interactive and include homework assignments to help maintain focus on the leadership training between sessions. Women leaders in academe and industry are guest speakers and serve as important role models for participants.

Before and during the sessions, participants completed inventories measuring perceptions of leadership skills, communication styles, and conflict resolution mode. Guest speaker/role models are a particularly important feature of the Institute. Guest speakers were drawn from a range of fields and positions. Following is a listing of year 1 guest speakers.

- $\quad$ Former university president

- Current university chancellor

- $\quad$ Two university curators (university governing board)

- $\quad$ Former Ms. Black America

- $\quad$ Current department chairwoman

- $\quad$ Industry vice-presidents

- $\quad$ University and consulting finance officers

The Leadership Institute is designed to help participants bridge the gap between faculty responsibilities and leadership positions. Through the Leadership Institute, participants

1. gain basic knowledge of leadership dynamics in the higher education organizational setting;

2. increase self-awareness in personal leadership styles and understand the potential implications of future leadership roles in higher education;

3. be able to distinguish between leadership and management and the relevant applications for higher education;

4. develop basic knowledge of communication dynamics within higher education organizations;

5. enhance self-awareness of their personal communication style and understand its implications for their future leadership roles in higher education;

6. gain basic knowledge of strategic financial management as practiced in higher education;

7. develop a basic understanding of strategies by which to build and sustain effective external relationships with key stakeholders; and

8. develop a personal action plan for sustaining personal health and life balance while achieving professional success in leadership roles in higher education. 
Session topics and assignments included the following:

Table 1. Leadership Institute Activities

\begin{tabular}{|ll|}
\hline Part I (Days 1 and 2) \\
1. & Leadership in Public Service Organizations \\
2. & Leadership perspectives \\
3. & Effective Leadership Behaviors \& Practices \\
4. & Communication and higher education organizations \\
5. & Strategic Management in higher education organizations \\
6. & EIQ: The Other Side of Leadership \\
7. & Introduction to Strategic Financial Management \\
8. & The business of mentoring \\
\hline Intersession homework: \\
1. & Each participant was tasked with learning about the budgeting structure at her \\
& university. The assignment included collecting typical financial reports for \\
2. & Eachartment chairs and interviewing their fiscal officer. \\
& was asked to report to the Institute group how they established a relationship or \\
& how they intended to enhance the relationship with their mentor. \\
\hline $\begin{array}{l}\text { Part II (Days } 3 \text { and 4) } \\
\text { 1. }\end{array}$ & Strategic Financial Management (part II) \\
2. & Conflict management \\
3. & Strategic management in higher education organizations \\
4. & Life balance and prime time \\
5. & Personal action plan \\
6. & The business of coaching and mentoring \\
7. & Attitude and image \\
&
\end{tabular}

\section{LEADERSHIP INSTITUTE PARTICIPATION AND EVALUATION}

\section{A. Participants and procedures}

The first author sent a letter to provosts at colleges and universities in the central Midwest asking them to identify and pass on information to tenured women faculty in NSF-supported disciplines who might be interested in developing leadership skills. These women faculty members then completed an online application for the Leadership Institute (http://o.web.umkc.edu/obannond/ADVANCE/ADVANCE.html). Selection criteria included faculty membership in NSF-supported areas and prior award of tenure. Participants could be faculty members or current university administrators who met the selection criteria. Participants were responsible for travel and lodging, but all costs associated with the Institute were paid for by the NSF-ADVANCE award.

Twenty-three applicants met the selection criteria and were invited to attend the Leadership Institute. Of those, 16 completed all components of the first year Institute. We attracted women faculty from research intensive, doctoral-granting, and comprehensive universities from across the country. One participant was from an historically black university. Three women were in 
their 30s, 8 in their 40s, 4 in their 50s, and 1 did not report. All women held a Ph.D. The racial composition of the group is presented in the following pie chart (Figure 1).

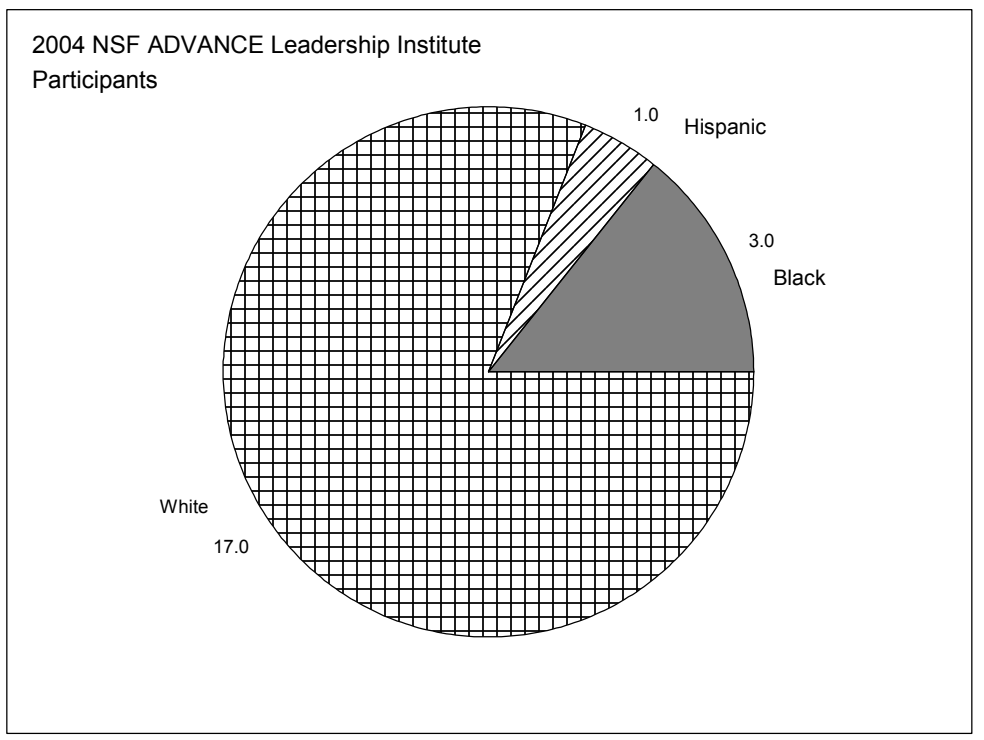

\section{Figure 1. Ethnicity of Year One Participants}

One of our primary goals was to attract women from the disciplines of science, math and technology. Year one participants represent a range of fields. Most participants were serving in non-administrative faculty roles at their university, as shown in Table 2.

Table 2. Participants' primary discipline, current position, and career aspirations

\begin{tabular}{|l|l|l|}
\hline Disciplines & Positions & Aspirations \\
\hline $\begin{array}{l}\text { Agriculture \& Natural Sciences } \\
\text { Biology (2) }\end{array}$ & Associate Professor (9) & Central Administrator (2) \\
Biomedical Engineering (1) & Department Chair (6) \\
Cell Biology \& Biophysics (1) & Center Director (1) & Dean (6) \\
Chemistry (1) & Assistant Dean (1) & \\
Economics (1) & Associate Vice Provost (1) & \\
Engineering (3) & & \\
Engineering Management (1) & & \\
\hline
\end{tabular}

Proceedings of the 2005 American Society for Engineering Education Annual Conference \& Exposition Copyright (C)2005, American Society fro Engineering Education 


\begin{tabular}{|l|l|l|}
\hline Geology \& Geophysics (1) & \\
Mathematics (1) & & \\
Statistics (1) & & \\
Teacher Ed-Science (2) & & \\
\hline
\end{tabular}

\section{B. Assessment and Evaluation}

To measure the impact of the Leadership Institute on the careers of participants, we will collect five years of longitudinal data on the leadership activities of participants. We asked participants to provide their current leadership activities when they applied for the Institute. These data serve as the baseline measure of leadership activities. At the end of each academic year for five years, we will email participants and ask them to report leadership activities from that academic year.

For individual assessment of leadership potential, we administered the Leadership Practices Inventory-Updated (LPI; Posner \& Kouzes, 1993). The inventory is designed to measure five practices--Model the way, Inspire a shared vision, Challenge the process, Enable others to act, and Encourage the heart. Thirty items are rated on a 10-point scale where higher scorers equal greater evidence of the practice. Participants completed a Self survey and asked a supervisors, peers, and direct reports to complete Observer surveys. Each individual LPI report provides graphs with the ratings from each type of respondent so that the participant may compare her perceptions of her own leadership practices with the perceptions of supervisors, peers, and subordinates. The LPI was administered prior to the first session and will be administered again at the end of the $3^{\text {rd }}$ and $5^{\text {th }}$ year following the workshop.

Each of the two leadership sessions were evaluated by participants with regard to usefulness of the information provided and level of participant satisfaction with the materials, presentation, speakers, facilities, etc.

\section{YEAR ONE RESULTS}

\section{A. Baseline Status and One Year Leadership Roles}

A summary of year one findings is presented in Table 3. A major purpose of the Institute was to provide leadership training to those women faculty who were not yet in administrative positions, but who might be considering leadership roles in academe. Although most participants were not administrators, many performed leadership activities in professional associations or within their academic departments. The baseline leadership activities in Table 3 include current and past activities. End-of-year 1 leadership activities include ongoing activities as well as those that were added since the initial Leadership Institute session. Participants were provided a copy of their baseline data when they were asked to report end of year 1 leadership activities. In Table 3 below, the number following each activity represents the number of times the activity was reported. Participants could report an activity more than once. For example, a participant might be involved in multiple professional organizations and hold leadership roles in more than one; therefore, her data would include at least two activities under professional association leadership. 
Table 3. Participants' Leadership Activities

\begin{tabular}{|c|c|c|}
\hline & $\begin{array}{l}\text { Baseline leadership } \\
\text { activities } \\
\text { (number of activities } \\
\text { reported) }\end{array}$ & $\begin{array}{l}\text { End of year } 1 \text { leadership } \\
\text { activities (number of } \\
\text { activities reported) }\end{array}$ \\
\hline $\begin{array}{l}\text { Professional association leadership } \\
\text { including officer roles, conference } \\
\text { organization, conference session } \\
\text { organization }\end{array}$ & 14 & 15 \\
\hline Department chair, division head & 6 & 5 \\
\hline Academic program director & 6 & 5 \\
\hline Assistant dean & 1 & none reported \\
\hline Central administrator & 1 & none reported \\
\hline Senior administrative fellow & 2 & 1 \\
\hline Campus committee chairperson & 1 & 7 \\
\hline $\begin{array}{l}\text { Principal investigator for grant-funded } \\
\text { project }\end{array}$ & 2 & 3 \\
\hline $\begin{array}{l}\text { Project leader (e.g. grant administrator, } \\
\text { research director) }\end{array}$ & 1 & 7 \\
\hline Program evaluator for accrediting body & 1 & 1 \\
\hline Center director & 3 & 2 \\
\hline $\begin{array}{l}\text { Academic journal editor or editorial } \\
\text { assistant }\end{array}$ & 1 & 1 \\
\hline Other & 0 & 10 \\
\hline
\end{tabular}

B. Individual Assessment

The LPI baseline results for the group are presented in Figure 2 below. As discussed earlier, participants completed a Self inventory and supervisors, direct reports, and peers completed Observer inventories. Data from 16 Self inventories and 58 Observer inventories are included in the results. 
Session 2692

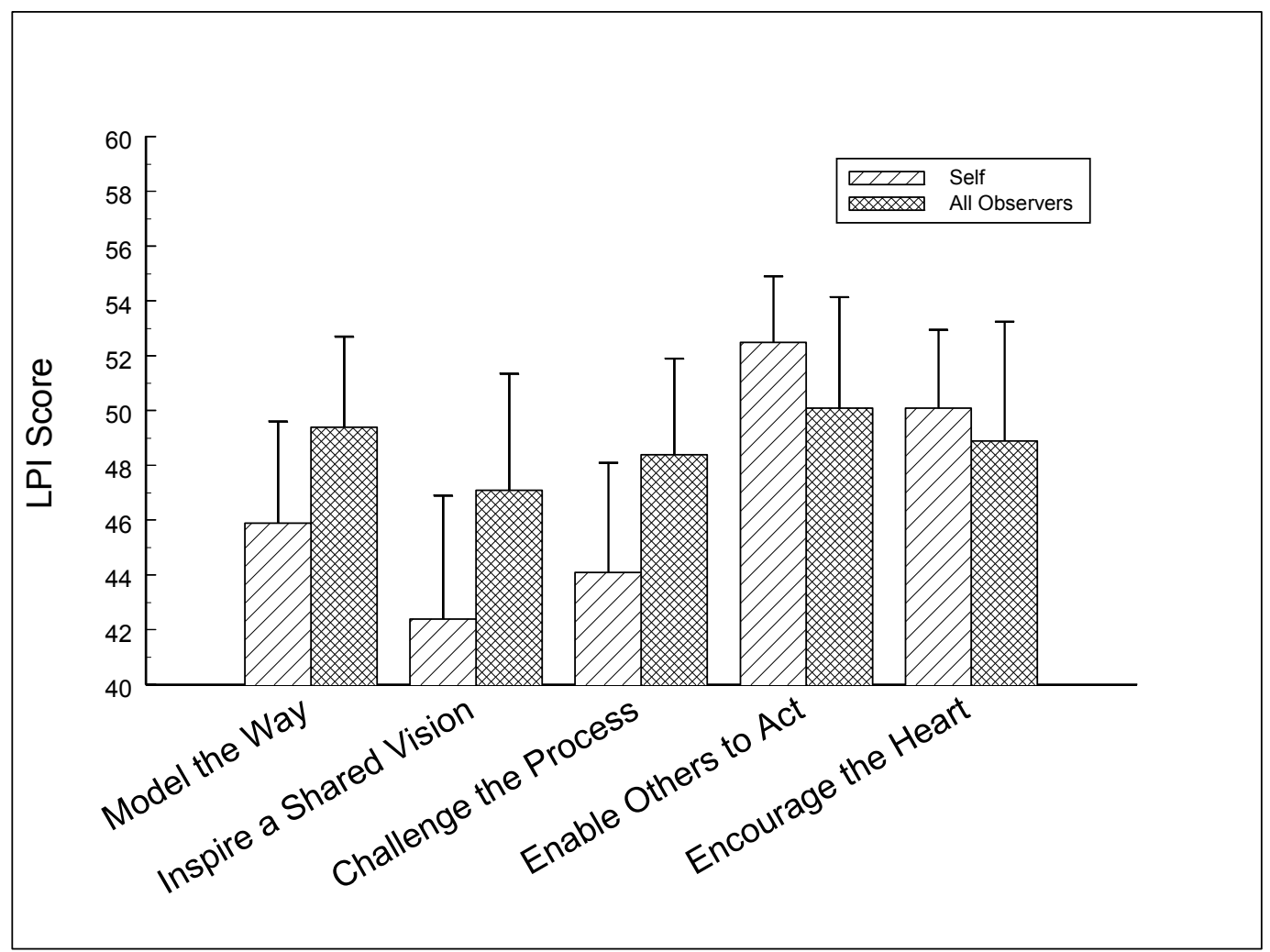

Figure 2. Summary of the Five Leadership Practices Inventory Baseline Results (standard deviation indicated by error bars)

C. Institute Evaluation

At the conclusion of the two-session Institute, participants completed a brief survey asking them to rate the quality of the Institute and identify the most beneficial and useful aspects of the Institute. On a 5-point scale, participants reported being satisfied with the

q quality of instructional delivery (mean rating $=4.6$ ),

口 quality of instructional materials (mean rating $=4.4$ ),

- relevance of instructional activities (mean rating $=4.3$ ), and

- opportunities to analyze or evaluate their personal leadership skill/potential (mean rating $=4.4$ ).

In response to the question, "What were the major benefits you received from participating in the Leadership Institute," participants reported that the Institute

- "Gave me a good chance to look objectively at myself and my career goals" $(\mathrm{n}=14)$

- "Presented new ideas and approaches" $(n=14)$

- "Acquainted me with problems and solutions" $(\mathrm{n}=12)$

- "Helped confirm some of my ideas" $(n=9)$

- Other $(\mathrm{n}=4)$ :

Proceedings of the 2005 American Society for Engineering Education Annual Conference \& Exposition Copyright (C)2005, American Society fro Engineering Education 
- "Networking" $(\mathrm{n}=2)$

- "Allowed me to understand the dynamics of leadership, the responsibilities that go with it, conflict management, my current leadership style \& how to project my image more positively"

- "Support"

In response to the question, "What part of the Leadership Institute was most useful to you," participants responded

- Personal inventories of communication and conflict style $(n=7)$

- Strategic planning $(\mathrm{n}=6)$

- Conflict resolution $(\mathrm{n}=5)$

- Guest speakers, role models $(\mathrm{n}=5)$

- Leadership Practices Inventory $(\mathrm{n}=3)$

- General management $(\mathrm{n}=2)$

- Financial reporting and planning $(\mathrm{n}=1)$

- Mentoring $(\mathrm{n}=1)$

- "Know yourself" aspects $(\mathrm{n}=1)$

- Case studies $(\mathrm{n}=1)$

- Networking $(\mathrm{n}=1)$

- Image issues $(\mathrm{n}=1)$

- Ethical issues $(\mathrm{n}=1)$

- Discussion of the work of department chairs $(\mathrm{n}=1)$

- I will incorporate everything that I have learned $(n=1)$

\section{DISCUSSION}

The purposes of this paper were to describe a leadership institute developed to train future women faculty leaders in STEM disciplines and to present the results of a year-one implementation of the leadership institute. The primary aim of the institute is to facilitate the movement of tenured women STEM faculty into academic leadership positions, thereby increasing the number of women in these positions.

First, we sought to attract women participants who met two criteria: STEM discipline and tenured status. Sixteen women met these criteria and completed all aspects of the institute. Many STEM disciplines were represented ranging from engineering to biology. Most participants $(\mathrm{n}=9)$ hold the Associate Professor rank (see Table 2). Two participants were full professors and the remainder were academic administrators. Participants' aspirations with regard to administrative roles were fairly evenly split with six aspiring to the department chair-level and six to a deanship. Two participants aspired to positions in central administration, and the remaining two were interested in entrepreneurial opportunities.

Institute participants reported a range of current leadership activities on the application for the institute. In our analysis, we noted a weakness in the data collection tool and the data in Table 3 should be interpreted with caution. Specifically, participants responded to an open-ended question asking them to list their leadership activities at baseline and again in a end-of-year 1 follow-up survey. However, even though the question was the same, participants appear to have interpreted the question more broadly in the follow-up and responded with a wide range of 
activities that were not reported in the baseline survey, such as "organizer of a new faculty orientation," "supporting students participating in a student-faculty engagement focus group," and "becoming increasingly involved in the recruitment of women faculty and two-body hires." We intend to rectify this problem in the future by providing a checklist of activities and specific examples of leadership roles.

A particularly well-received aspect of the institute was the opportunity to explore individual leadership, communication, and conflict resolution styles. Because our focus is on leadership development, we are collecting those data at three different points in time to measure change. To date, we have collected the baseline data and the results are presented in Figure 2. The Kouzes $\&$ Posner leadership inventory assesses five leadership practices with ratings by the individual as well as several observers. Comparisons between Self rating and those of the Observers indicated that participants, as a group, rated themselves lower on Model the way, Inspire a shared vision, and Challenge the process. In contrast, participants rated themselves higher on average than observers on Encourage the heart, and Enable others to act. This last finding suggests that these women faculty in STEM disciplines perceive their interpersonal leadership to be more positive or effective than do others. Participants reported that reflections such as these were interesting and helpful.

Overall, participants' evaluation of the leadership institute was very positive. Ratings for the quality of the institute were high for all categories. In addition, participants reported many beneficial and useful aspects of the institute.

In summary, the first year of this three-year program was very successful. Well-qualified women faculty participated in the first leadership institute and they reported that they benefited from the experience. The data from the first cohort will be used to modify instruction and materials for subsequent cohorts. We will continue to collect data form the year 1 participants for a period of five years to track changes in their leadership activities over time.

\section{References}

2004. Rodney D. Chipp Memorial Award: Jean-Lou A. Chameau, Ph.D. SWE 50(5):29.

Greene, T.J. and N.E. Van Kuren. 1995. Tips for Would-be Administrators. ASEE Prism 4(8):26-28.

Greenwood, M. 2000. Advancing women into science leadership. In Who Will do the Science of the Future? A Symposium on Careers of Women in Science National Academy of Sciences, Committee on Women in Science and Engineering. National Academy Press, Washington, DC, 2000. 87+xiii.

Layne, P. 2003. Women Engineers as Leaders in Academe, part II. SWE 49(4): 26,28,30.

Lively, K. 2000. Women in Charge: more elite universities hire female provosts, creating a new pool for presidential openings. The Chronicle of Higher Education (June 16, 2000).

Long, J.S., ed. 2001. From Scarcity to Visibility: Gender Differences in the Careers of Doctoral Scientists and Engineers. National Research Council, Washington, D.C.

McKenney, C.B. and B.D. Cejda. 2001. The Career Path and Profile of Women Chief Academic Officers in Public Community Colleges. Advancing Women in Leadership

(http://www.advancingwomen.com/awl/summer2001/index.html), Vol. 9, No. 1. 
National Academy of Sciences. 2002. Advancing Women into Science Leadership. A Symposium on Careers of Women in Science. Pages 57-73.

Nelson, D.J. 2002. The Nelson Diversity Surveys (http://cheminfo.chem.ou.edu/faculty/djn/diversity/top50.html).

Posner, B.Z, and Kouzes, J.M. 1991. Psychometric properties of the Leadership Practices Inventory-Updated. Educational and Psychological Measurement, 53, 191-199.

\author{
Acknowledgments \\ The NSF ADVANCE Leadership Institute was supported by a grant from the National Science Foundation \\ ADVANCE program (SBE-0318248).
}

\title{
Authors' Biographies
}

Deborah O'Bannon is an Associate Professor of Civil Engineering at the University of Missouri-Kansas City, and is Principal Investigator on the NSF ADVANCE grant. She has been active in the Society of Women Engineers at the national level, by serving on the Board of Directors and Editorial Board for their print publication, and named as a Fellow in 2002. She is currently the ABET coordinator, and teaches a variety of civil engineering courses. She has degrees from MIT (BSCE), Manhattan College (M.Eng.) and University of Iowa (Ph.D.).

Address: 350L Flarsheim Hall, University of Missouri-Kansas City, 5100 Rockhill Road, Kansas City, MO 64110; Telephone: 816-235-1287; Facsimile: 816-235-1260; Email: obannond@umkc.edu

Linda Garavalia is the Assessment Administrator for the ADVANCE Leadership Institute. She is also an Associate Professor in the Psychology Department at the University of Missouri-Kansas City and teaches graduate and undergraduate courses in assessment, educational research methods, program evaluation, and educational psychology. She publishes regularly in scholarly journals and frequently serves as an assessment consultant for campus academic units and community organizations. She has a B.A. from Clemson University, M.A. in journalism and Ph.D. in Educational Psychology and Research from the University of South Carolina.

Address: 4825 Troost, Suite 124, University of Missouri-Kansas City, 5100 Rockhill Road, Kansas City, MO 64110; Telephone: 816-235-2490; Facsimile: 816-235-1062; Email: garavaliaL@umkc.edu

David Renz holds the Beth K. Smith/Missouri Chaired Professorship in Nonprofit Leadership and is the Director of the Midwest Center for Nonprofit Leadership, the education, research and outreach center of the Bloch School of Business \& Public Administration at the University of Missouri-Kansas City that works to build leadership and management capacity in nonprofit and public service organizations. He has a Ph.D. in Organization Theory and Administration from the University of Minnesota.

Address: 310 Bloch, University of Missouri-Kansas City, 5100 Rockhill Road, Kansas City, MO 64110;

Telephone: 816-235-2342; Facsimile: 816-235-1169; Email: renzd@umkc.edu

Marie McCarther is Senior Fellow and Director of The Forum for Early Childhood Organization and Leadership Development, a program of the Midwest Center for Nonprofit Leadership in the Bloch School of Business and Public Administration at the University of Missouri-Kansas City. She brings extensive experience in leadership development programming and as an educator and executive in educational organizations. She has an Ed.D. from the University of Cincinnati.

Address: 310 Bloch, University of Missouri-Kansas City, 5100 Rockhill Road, Kansas City, MO 64110; Telephone: 816-235-5554; Facsimile: 816-235-1169; Email: mccarthers@umkc.edu. 